\title{
Impact of Certain Pesticides on Urease and Dehydrogenase Enzymes in Soil during the Cotton Bollworms Control
}

\author{
EL-Naggar, A.Z ${ }^{1}$
}

\begin{abstract}
The present study was carried out on soil cultivated with cotton variety Giza 70 during the season of 2011 to determine the side effects of certain pesticides i.e.; chlorpyrifos, profenofos, cypermethrin and alphacypermethrin which were used against the cotton bollworms on soil enzymes of urease and dehydrogenase. Three sprays for each insecticide were done and the spraying is carried two weeks after the previous spray.

The average of urease activity for the three sprays were expressed as unconverted urea to $\mathrm{NH}_{4}-\mathrm{N}(\%)$. The results showed high enzyme activity in all treatments, while, the mean enzyme activity was significantly decreased after treatment with profenofos.

For the average of enzyme dehydrogenase activity for the three sprays that expressed part per million (ppm) Formazan were determined. The results showed higher enzyme activity after application with chlorpyrifos, while, the activity was significantly decreased after application with Cypermthrin and profenofos, but, alphacypermethrin had mild effect on the enzyme.

It concluded that profenofos reduced urease and dehydrogenase activities. While cypermthrin decreased dehydrogenase activity . On the other hand, chlorpyrifos increased urease and dehydrogenase activities.
\end{abstract}

\section{INTRODUCTION}

In Egypt, the cotton crop occupies the most important place among agriculture strategy. The cotton production suffers from the injury of numerous pests. Hence, different chemical groups of pesticides are applied every season to control these pests particularly the cotton bollworms. The impact of pesticides on plants and soil attracted the attention of many investigators (EL-Shahaat et al., 1987, Ramadan, 1991, El- Shahaat and Edrisha, 1993 and Ahmed, 2002 and EL-Shahaat et al., 2007).

Therefore, the present study was conducted to evaluate the side effects of chlorpyrifos, profenofos, cypermethrin and alpha-cypermethrin insecticides on the soil enzymes activity as urease and dehydrogenase during the application of these insecticides against the cotton bollworms.

\section{MATERIALS AND METHODS}

\section{1- Experiments}

The field experiments were started on Aug the $17^{\text {th }}$ 2011 in cotton field (Giza 70 variety) at Beheira governorate. The evaluated treatments as well as a check treatment were distributed in a complete block randomized design.

\section{2 - Pesticides used:}

A- Chlorpyrifos, $48 \quad \%$ EC $\left(\right.$ Pyriban $\left.^{\circledR}\right)$ as an organophsphorus insecticide. Its recommended rate of application is $1 \mathrm{~L} /$ feddan .

B- Profenofos $72 \%$ EC $\left(\operatorname{Cord}^{\circledR}\right)$ as an organophsphorus insecticide. Its recommended rate of application is $750 \mathrm{~cm}^{3} /$ feddan

C- Cypermethrin $25 \%$ EC $\left(\right.$ Sparkil $^{\circledR}$ ) as a pyrethroid insecticide. Its recommended rate of application is $250 \mathrm{~cm}^{3} /$ feddan.

D- Alpha-cypermethrin $15 \%$ EC (Pestox $\mathrm{KZ}^{\circledR}$ ) as a pyrethroid insecticide. Its recommended rate of application is $165 \mathrm{~cm}^{3} /$ feddan.

Three sprays for each insecticide were done and the spraying is carried two weeks after the previous spray.

\section{3 - Assay of soil enzymes}

\section{A. Soil treatment}

Samples of clay loam soil that previously planted with cotton was air-dried and sieved. Soil samples (500g-each) were taken weekly and transferred into plastic pots. The commercial formulations (EC) of chlorpyrifos, profenofos, cypermethrin and alphacypermethrin pesticides were applied at the recommended rates according to the Ministry of Agriculture, Egypt. The soil moisture content was brought to $60 \%$ of its field capacity and maintained constant through certain experimental periods.

\section{B. Dehydrogenase activity assay:}

The soil dehydrogenase enzyme activity can be considered as an indicator to the oxidative biological activities (Casida et.al., 1964) and soil respiration (Stevenson, 1959). Dehydrogenase activity in soil was determined according to the reduction of 2, 3, 5tripheneyltetrazolium chloride (T.T.C) to triphenyl formazan (T.P.F) which is extracted and measured spectrophotometrically (Casida et al., 1964).

To assay this enzyme activity, triphenyl tetrazolium chloride (TTC) was used as a substrate that is enzymatically converted to triphenyl formazan (TPF). The obtained formazan calibration curve shows an

\footnotetext{
${ }^{1}$ Plant Protection Res., Institute Agric. Res. Center, Alex., Egypt

Received Febuary 28, 2013, Accepted March 28, 2013
} 
extinction coefficient " $\mathrm{K}$ " as $33 \times 10^{-4}$ with a maximum absorbance at $485 \mathrm{~nm}$.

\section{Urease activity}

It is known that urea is used as a source of nitrogen fertilizer that requires an enzymatic hydrolysis to make its nitrogen content available to plants. Urease enzyme in soil is the enzyme that can convert urea to $\mathrm{NH}_{4}-\mathrm{N}$ that is considered as start material can be oxidized to produce nitrate. Thus, a serious problem may arise when urea fertilizer was added to soil having low urease activity (Lieoyd and Sheaffe, 1973 and Lethbridge et al., 1981). The urease activity is spectrophotometrically determined according to Watt and Chrisp (1954). Urea contents were expressed as micrograms urea / gm airdried soil.

The urease activity was determined as the following formula:

Urease activity $\%=\frac{A-B}{A} \times 100$

Where:

A: the original urea added (ppm).

$\mathrm{B}$ : the remaining urea (residues) in ppm.

A- B = the converted amount of urea in ppm.

D. Statistical analysis:

The obtained results were expressed on the base of the air dried soil. The analysis of variance of treated and untreated soils with 3 replicates $\mathrm{x} 3$ determinations was carried out. The means of treatments were compared for significance by the least significant difference (L.S.D) measure at the probability level of 0.05 .

\section{RESULTS AND DISCUSSIONS}

\section{Effect on urease enzyme:}

Urease enzyme is microbially released in soil to catalyse the hydrolysis of urea fertilizer to ammonical nitrogen, $\mathrm{NH}_{4}-\mathrm{N}$. The later is the starting substance for the nitrification process; oxidation of $\mathrm{NH}_{4}-\mathrm{N}$ to nitrite$\mathrm{N} ; \mathrm{NO}_{2}-\mathrm{N}$ and nitrate-nitrogen $\left(\mathrm{NO}_{3}-\mathrm{N}\right)$. Therefore, there is a negative correlation between unconverted urea amount and the urease activity.

The results shown in Table, 1 appeared that urease activity was highly decreased in profenofos - treated soil $(66.24 \%)$ compared with the untreated check (74.67 \%), while, the highest urease activity was recorded with the treatment of Chlorpyrifos (81.72). There were no significant differences between the $1^{\text {st }}$ and $2^{\text {nd }}$ spray for all treatments. In the $3^{\text {rd }}$ spray, the urease activity \% showed to be the highest decreased activity value with profenofos (44.7\%), while, cypermthrin and chlorpyrifos caused the highest increase in urease activity (887 and 86.4 , in respect).

\section{Effect on Dehydrogenase enzyme:}

The influences of the tested pesticides on soil dehydrogenase activity are shown in Table, 2 . The mean activities of the enzyme were highly decreased where formazan content are 24.3, 27.2 and $30.2 \mathrm{ppm}$ for the treatments of cypermthrin, profenofos and alphacypermethrin, respectively in comparison to untreated control; $36.7 \mathrm{ppm}$. The dehydrogenase activity had the highest decreasing value in the $1^{\text {st }}$ spray $(18.1 \& 22.5$ ppm) with cypermthrin and alpha-cypermethrin, respectively, while, the activity was decreased in the $2^{\text {nd }}$ spray of profenofos, alpha-cypermethrin and cypermthrin $(32.9,34.9$ and 35.9 , in respect).

\section{Table 1. Effect of certain pesticides on soil urease enzyme activity in cotton crop field during} season of 2011

\begin{tabular}{|c|c|c|c|c|c|}
\hline \multirow{3}{*}{ Intervals } & \multicolumn{5}{|c|}{ Urase activity \% } \\
\hline & \multicolumn{5}{|c|}{ Treatments } \\
\hline & $\begin{array}{l}\text { Untreated } \\
\text { check }\end{array}$ & $\begin{array}{c}\text { Alphacypermethrin } \\
\text { EC 15\% }\end{array}$ & $\begin{array}{l}\text { Chlorpyrifos } \\
\text { EC 48\% }\end{array}$ & $\begin{array}{c}\text { Profenofos } \\
\text { EC 72\% }\end{array}$ & $\begin{array}{c}\text { Cypermethrin } \\
\text { EC 25\% }\end{array}$ \\
\hline $\begin{array}{l}\text { The } 1^{\text {st }} \text { spray (Aug., } \\
17,2011 \text { ) }\end{array}$ & $67.3 \mathrm{~b}$ & $79.2 \mathrm{a}$ & $78.0 \mathrm{a}$ & $76.2 \mathrm{a}$ & $76.5 \mathrm{a}$ \\
\hline $\mathrm{LSD}_{.05}$ & \multicolumn{5}{|c|}{4.132} \\
\hline $\begin{array}{l}2^{\text {nd }} \text { spray ( } 2 \text { weeks post } \\
\text { the } 1^{\text {st }} \text { spray) }\end{array}$ & $78.3 \mathrm{a}$ & $77.8 \mathrm{a}$ & $80.8 \mathrm{a}$ & $77.8 \mathrm{a}$ & $77.7 \mathrm{a}$ \\
\hline $\mathrm{LSD}_{.05}$ & \multicolumn{5}{|c|}{2.87} \\
\hline $\begin{array}{l}3^{\text {rd }} \text { spray ( } 2 \text { weeks post } \\
\text { the } 2^{\text {nd }} \text { spray) }\end{array}$ & $78.4 \mathrm{~b}$ & $79.1 \mathrm{~b}$ & $86.4 \mathrm{a}$ & $44.7 \mathrm{c}$ & $87.0 \mathrm{a}$ \\
\hline $\mathrm{LSD}_{.05}$ & \multicolumn{5}{|c|}{6.36} \\
\hline Mean & $74.67 \mathrm{c}$ & $78.72 \mathrm{~b}$ & $81.72 \mathrm{a}$ & $66.24 \mathrm{~d}$ & $80.43 \mathrm{ab}$ \\
\hline $\operatorname{LSD}_{.05}$ & \multicolumn{5}{|c|}{2.359} \\
\hline
\end{tabular}


Table 2. Effect of certain pesticides on soil dehydrognase enzyme activity in cotton crop field during season of 2011

\begin{tabular}{|c|c|c|c|c|c|}
\hline \multirow{3}{*}{ Intervals } & \multicolumn{5}{|c|}{ Dehydrognase enzyme (formazan, ppm) } \\
\hline & \multicolumn{5}{|c|}{ Treatments } \\
\hline & $\begin{array}{c}\text { Untreated } \\
\text { check }\end{array}$ & $\begin{array}{c}\text { Alphacypermethrin } \\
\text { EC 15\% }\end{array}$ & $\begin{array}{c}\text { Chlorpyrifos } \\
\text { EC } 48 \%\end{array}$ & $\begin{array}{l}\text { Profenofos } \\
\text { EC 72\% }\end{array}$ & $\begin{array}{l}\text { Cypermethrin } \\
\text { EC 25\% }\end{array}$ \\
\hline $\begin{array}{l}\text { The } 1^{\text {st }} \text { spray (Aug., } \\
17,2011 \text { ) }\end{array}$ & $21.4 \mathrm{bc}$ & $22 . .5 \mathrm{bc}$ & $48.9 \mathrm{a}$ & $32.8 \mathrm{~b}$ & $18.1 \mathrm{c}$ \\
\hline $\mathrm{LSD}_{.05}$ & \multicolumn{5}{|c|}{11.73} \\
\hline $\begin{array}{l}2^{\text {nd }} \text { spray ( } 2 \text { weeks post } \\
\text { the } 1^{\text {st }} \text { spray) }\end{array}$ & $60.6 \mathrm{~b}$ & $34.9 \mathrm{c}$ & $143.5 \mathrm{a}$ & $32.9 \mathrm{c}$ & $35.9 \mathrm{c}$ \\
\hline $\mathrm{LSD}_{.05}$ & \multicolumn{5}{|c|}{22.37} \\
\hline $\begin{array}{l}3^{\text {rd }} \text { spray ( } 2 \text { weeks post } \\
\text { the } 2^{\text {nd }} \text { spray) }\end{array}$ & $28 \mathrm{abc}$ & $33.2 \mathrm{ab}$ & $39.4 \mathrm{a}$ & $15.9 \mathrm{c}$ & $19.0 \mathrm{bc}$ \\
\hline $\mathrm{LSD}_{.05}$ & \multicolumn{5}{|c|}{15.78} \\
\hline Mean & $36.7 \mathrm{~b}$ & $30.2 \mathrm{bc}$ & $77.3 \mathrm{a}$ & $27.2 \mathrm{c}$ & $24.3 \mathrm{c}$ \\
\hline $\mathrm{LSD}_{.05}$ & \multicolumn{5}{|c|}{9.440} \\
\hline
\end{tabular}

** The values having the same letter(s) are not significant differed

In the $3^{\text {rd }}$ spray, the treatments of profenofos and cypermthrin decreased the activity values as 15.9 and 19.00, respectively. On the other hand, the enzyme activity was increased by chlorpyrifos; $77.3 \mathrm{ppm}$ formazan. The dehydrogenase activity increased after application of chlorpyrifos in the three successive sprays with dehydrogenase activity $(48.9,143.5$ \& 39.4 ppm, respectively).

The results indicated that urease and dehydrogenase enzymes were affected by the tested pesticides. These findings are in agreement with those reported by many investigators; El-Shahaat et al. (1989) when they found that cypermethrin and fenvalerate pyrethroids inhibited dehydrogenase activity in a sandy clay loam soil. Nevertheless, certain pyrethroids appeared to affect the urease activity with a positive correlation as reported by Chapman et al. (1981). The depression of soil enzyme activities by a pesticide could be attributed to the detrimental influence or its degradation products on enzyme-producing microorganisms (Kuseske et al., 1974 and Richey et al., 1977). El-Shahaat et al. (1989) found that the dehydrogenase and urease activity were mainly affected by the pesticides; and not by the type mineral or/and fertilization.

The obtained reducing effect on urease activity may be desirable where the heavy use of urea as fertilizer can produce certain problems encountered in the use of urea. These problems resulted from rapid hydrolysis of this fertilizer to ammonium carbonate, in the presence of soil calcium carbonate, leading to increase soil $\mathrm{pH}$ and liberation of $\mathrm{NH}_{4}-\mathrm{N}$. The obtained adverse effect can induce damage to germinating seedlings and young plants as well as inducing nitrite $\left(\mathrm{NO}_{2}-\mathrm{N}\right)$ and / or ammonium-toxicity and gaseous loss of urea nitrogen as $\mathrm{NH}_{3}-\mathrm{N}$ (Kiss et al., 1973 and Lethridge et al., 1981).
In contrast, the stimulatory effect that may be occurred by a pesticide on soil enzymes may be due to the utilization of this chemical compound by soil microorganisms as explained by many investigators (Vaankateswarlu and Sethunathan, 1979 \& Tu, 1980).

\section{REFERENCES}

Ahmed, I.A., M.S. EL-Shahaat, M.S.Nassar, Kh.A. Abd ELRahman and H.S. Radwan (2002). Pesticides-soil relationships. III. Influence of three pesticides on soil stages of some non-target insects. J. Adv. Agric. Res. Vol.

Casida, L.E. Jr, D.A. Klein, and T. Santoro (1964). Soil dehydrogenase activity. Soil Sci., 98, 371-376.

Chapman, R.A., C.M. Tu, R. Harris, and C. Cole (1981). Persistence of five pyrethroids insecticides in sterile and natural, mineral and organic soil. J. Bull. Environ. Contam. Toxicol., 26: 513-519.

El-Shahaat, M.S., M.A. Othman, M. El-Halfway and A.S. Marie (1987). Effect of carbamate and synthetic pyrethroids pesticides on some soil microbial activities. Alex. J. Agric. Res. 32(1): 427-438.

El-Shahaat, M.S., M. Emarah and A.S. Marie (1989). Compatibility of certain pyrethroids-foliar fertilizer combinations in relation to soil biology. Alex. Sci. Exch., Vol. 10, (4): 603-626.

El-Shahaat, M.S. and M.S. Edrisha (1993). The impact of certain pesticides with cotton plants and soil. II. Effect of pyrethroids pesticides on cotton leaves and soil biological processes during bollworms control. Alex. J. Agric. Res. 38 (2): 399-417.

El-Shahaat, M.S., Mesbah, H.A, A.Z. EL- Naggar, E.H., Tayeb (2007). The relative efficiency of pesticides and fertilizers on cotton crop. II. The side effects of certain pesticides and fertilization types on the soil enzymes, urease and dehydrogenase. J. Adv. Agric. Res. 12 (1): 127-135. 
Kuseske, D.W., B.R. Funk, and J.T. Schulz (1974). Effects and persistence of Baygon (Propoxure) and Temic (Aldicarb) insecticides in soil. Plant and soil vol. 41:255269.

Kiss, M. Dragan- Bularda and D. Radulescu (1973). Biological significance of enzyme accumulated in soil. Adv. Agron., 27: 25-87.

Lethbridge, G., A.T. Bull, and R.G. Burns (1981). Effects of pesticides on 1, 3-B-glucaase and urease activities in soil in the presence and absence of fertilizer, lime and organic materials. Pestic. Sci. 12: 147-155.

Lieoyd, A.B and M.I. Sheaffe (1973). Urease activity in soils. Plant and soil, 39:71-80.

Ramadan, N.O.A. (1991). Efficacy measurements of three herbicides of the control of annual grasses in wheat. M.Sc. Thesis, plant Protec. Dep., Agric. Colege, King Saudi Univ. Riyadh, Saudi Arabia.
Richey, F.A., W.J. Bartley, and K.P. Sheets (1977). Laboratory studies on the degradation of the pesticide (Aldicarb) in soil. J.Agric. Food Chem. Vol. 25 (1): 4551.

Stevenson, IL. (1959). Dehydrognase activity in soil. Con. J. Microbial. Ottawa, 5: 229-235 (c.f. chem. Abs., 53: 16443f).

Tu, C.M. (1980). Influence of pesticides and some of the oxidized analogues on microbial population. Nitrification and respiration activities in soil. Bull. Environ. Contam. Toxical., 4: 13-19.

Vankateswarlu, K., and N. Sethunathan (1979). Metabolism of carbofuran in rice straw-amended and unamended rice soils. J. Environ. Qual. 8 (3): 365-368.

Watt, .C.W and J.D. Chrisp (1954). Spectrophotometric method for determination of urea. Anal. hem. 26: 452-453.

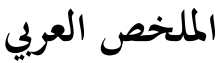

تأثير بعض المبيدات على أنزيمات اليوريز والدهيدروجينيز فى التربة خلال مكافحة ديدان

اللوز على القطن

$$
\begin{aligned}
& \text { على زكريا النجار } \\
& \text { إنخفض متوسط نشاط الأنزيم معنويا بعد المعاملة بمركب البروفينوفوس. } \\
& \text { تم إجـراء الدراسـة لهذا البحتث على التربـة المنزرعـة بصـف قطن } \\
& \text { أما أنزيم الدهيدروجينيز والتى يعبر عنها بجزء في المليون فورمازان. } \\
& \text { جيزة } 70 \text { في موسم } 2011 \text { وذلك بهدف دراسة تأثير بعض المبيدات }
\end{aligned}
$$

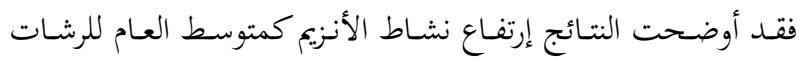

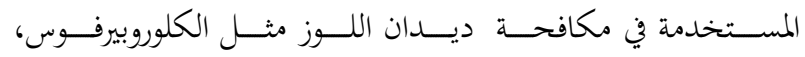

$$
\begin{aligned}
& \text { الثلاثة بعـد تطبيق مركب الكلوربيرفوس بينما إنخفض نشاط الأنزيم } \\
& \text { والبروفينوفـوس، والسـيبرمثيرن، وألفـا-سـيبرمثرين على أنزيمـات التربـة } \\
& \text { معنويا بعد المعاملة بكل من بروفينوفوس، سيبرمثرين. } \\
& \text { ونسـتخلص مـن النتـائج أن نشـاط كـل مسن أنزيمـات اليـوريز } \\
& \text { والدهيدروجينيز إنخفض بعد تطبيق مركب البروفينوفوس. أما مركب }
\end{aligned}
$$

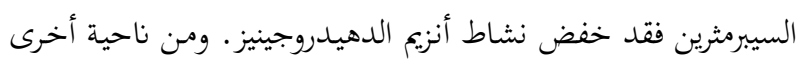

$$
\begin{aligned}
& \text { إرتفع نشاط كلا الأنزيمين زاد بعد تطبيق مركب الكلوربيرفوس. }
\end{aligned}
$$

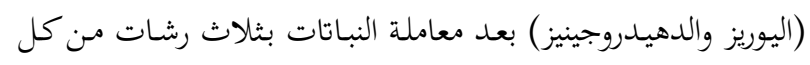

$$
\begin{aligned}
& \text { مبيد على فترات زمنية أسبوعين بعد كل رشة. } \\
& \text { ويمكن تلخيص النتائج المتحصل عليها كالأتى: } \\
& \text { تم تقدير نشاط أنزيم اليوريز على أساس قياس نسبة اليوريا المتحولة }
\end{aligned}
$$

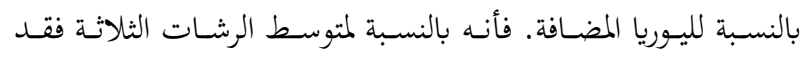

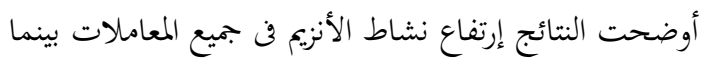

